\title{
On human cloning
}

\section{Robert Kelly}

Since cloning is a human idea, and the only people (as far as is known) who are doing cloning are human people, it is interesting to me to speculate on the mind sets from which we might turn out to be working.

I recall reading in a newspaper recently, among endless titillating speculations about cloning humans, some geneticist quoted as saying something to this effect: Well, we shouldn't get our hopes up too much-if we were able to clone Mozart, we might not get another great composer-we might just get a cab driver who liked to listen to music on the radio and hum.

What I found fascinating about the remark is that the geneticist (if indeed he really was one, not just a nameless authority) somehow imagined or intuited that music itself was part of the genetic package, even if genius wasn't. (My intuitions would point in the other direction, and suppose that genius or brain power-as great uncles used to call it-is more likely to be a physically conveyable capacity.)

If cloning Mozart is somehow involved with a taste for music, then a clone of Kant might have a taste for candied fruit and shooting pool, and a clone of Hitler would be nice to dogs. This seems close to nonsense, if not madness.

I am suggesting that, in the context of cloning humans, the question "What is being cloned?" properly understood requires a prior investigation of "What is a human?"

Since we are humans, and self-awareness does not appear to be an automatic faculty of our species (observe how our mythology sneers at Narcissus for his agenda of selfanalysis), the question of what is a human is just the sort of question that irritates the many, frustrates the technologist, enriches the philosopher. Most of us don't know the answer, but we know something that, for our practical purposes, is better than the answer. We know what a human does.

A human wants.

And what is bizarre, and it doesn't take Freud to know this, is that what humans want is infinitely various. Tastes and accomplishments and inclinations-whether they arise genetically (our cloned cabbie listening to Shostakovich) or environmentally (Irishmen tending to sing Irish songs) or

Robert Kelly is a poet who teaches in the writing program of Bard College, Annandaleon-Hudson, NY12504 (kelly@bard.edu) some other way (Mozart/muse/reincarnation)-whatever it is that humans want is also the token or totem of their self-definitions.

I am what I want. That seems to be the deepest truth for us, that we identify our very being with all of the many inclinations-sexual, political, ethical, religious, consociative-that we feel.

So from that point of view we might in

\section{It's time to think clearly}

about what we are, and what we want us to be. This life and next life. Who is it, what is it, that we want to clone?

fact discover that human cloning has been going on for years now, and its biochemistry is called propaganda or advertising, since by such means one human is made to inherit or inhabit the house of preference, the house of desire, built for another. But to go on in this vein would be spoilsport of me-I know what we all want, real cloning, hardedged science, the real thing, gold and pink and cocoa babies tumbling out of the assembly line full of All Desirable Qualities.

Do I err in supposing we should first really find out what these inclinations, velleities, tastes, desires really are? Should we find out whether or how they connect in turn with the creative or industrious qualities we seek to replicate by means of cloning?

At the moment, I am yielding to a trinitarian inclination, embedded in me by my language (your language, I'd say, if I were being confrontational), our Judaeo-Christian heritage, our trinitarian system of government. I am haunted by a trinitarian anxiety: I am afraid that when conception takes place in a living system, there is a father component and a mother component-and there may be something more.

This something more can be, if you like, dismissed as trinitarian guesswork or $\mathrm{Ol}^{\prime}$ Soul sneaking back in, and I won't quarrel with you too much. I think it's worth thinking about, though-just thinking, I mean. Not much here to measure. As with the behavior of subatomic particles, you can only see (if you can even see) where they've been, not where they are or what they're about to do now. What they're about to do next is dis- cussable only statistically.

And since statistics is a science that measures no thing, we could even think statistically about the Third Thing that creeps into the act of human conception. By and large, it seems to produce behavior oddly different from the behaviors of other animals we know much about, yet with odd kinships too. All creatures seem to know themselves from somebody else. All crows watch their backs. So there must be some sense of anxiety, some sense of identity conveyed by this Third Thing.

But this Third Thing when it involves humans seems to come bundled with a pressure to articulate, and hence symbolize, and hence eventually realize, the very inclinations that use for their own purposes the cellular hypostasis of body and consciousness with which the science of genetics concerned itself up till now.

I am daring to propose a sort of prolegomenon to any future human genetic engineering: such a study must carefully and sustainedly and subtly examine the very qualities we wish to replicate. The qualities we seek may be gifts of that Third Thing, and may accordingly be capable of being roused in us by acts of education and influence vastly beyond anything we've ever studied in our hard-edged conventional paideumas. It may be that the qualities we want can indeed be cloned, not by cloning the base metal of human gonadic production, but by influencing the consciousness of the parents, the consciousness of the fetus itself. Who can say?

We have not studied what precisely it is we want to achieve, and we will be in no real position to clone anything humanly worthwhile until we have done that intense and unprecedented work. Because the specific gifts of consciousness (Mozart, Fermat, Ramanujan, etc.) we want, and want to replicate, may be all round us, latent in us already, and may infuse individuals in subsequent generations without the prod of the geneticist's magic wand. The wand in question may be Hermes's staff itself, the meditative act which studies the world so quietly that the most contradictory serpents can peacefully twine round it.

I mean it's time to think clearly about what we are, and what we want us to be. This life and next life. Who is it, what is it, that we want to clone? Tread gently - we are on sacred ground. Vagueness here will certainly be the death of us. 